\title{
Evaluation of Winter-killed Cover Crops Preceding Snap Pea
}

\author{
Orion P. Grimmer and \\ John B. Masiunas ${ }^{1}$
}

Additional Index words. barley, Hordeum vulgave, oat, Avena sativa, snap pea, Pisum sativum var. macrocarpon, white mustard, Brassica hirta, weed control

Summary. Winter-killed cover crops may protect the soil surface from erosion and reduce herbicide use in an early planted crop such as pea (Pisum sativum). Our objective was to determine the potential of winter-killed cover crops in a snap pea production system. White mustard (Brassica birta) produced the most residue in the fall but retained only $37 \%$ of that residue into the spring. Barley (Hordeum vulgare) and oats (Avena sativa) produced less fall residue but had more residue and ground cover in the spring. Greater ground cover in the spring facilitated higher soil moisture, contributing to higher weed numbers and weight and lower pea yields for oat and barley compared with a bare ground treatment. White mustard had weed populations and pea yields similar to the bare ground treatment. Within the weed-free subplot, no differences in pea yields existed among cover crop treatments, indicating no direct interference with pea growth by the residues. In greenhouse experiments, field-grown oat and barley residue suppressed greater than $50 \%$ of the germination of common lambsquarters (Chenopodium album) and shepherd's-purse (Capsella bursapastoris), while in the field none of the cover crop provided better weed control than the fallow.

Department of Natural Resources and Environmen tal Sciences, University of Illinois, 260 Edward R Madigan Laboratory, 1201 W. Gregory Dr., Urbana, IL 61801

This paper is a portion of a thesis submitted by Orion Grimmer in partial fulfillment of the requirements for a Master of Science degree. We thank Fred Kolb for supplying many of the oat cultivars. Mention of a trademark, proprietary product, or vendor does not constitute a guarantee or warranty of the product by the University of Illinois and does not imply its approval to the exclusion of other products or vendors that also may be suitable.

${ }^{1}$ To whom reprint requests should be addressed. E-mail address: masiunas@uiuc.edu 


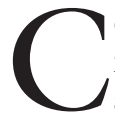
over crops may be grown to increase soil fertility, reduce soil erosion (Hoyt et al., 1994), suppress diseases (Muehlchen et al., 1990), and reduce weeds (Teasdale, 1996). Because spring snap pea is an early season crop, it could follow a fall-planted, winter-killed cover crop. Managing a cover crop residue mulch by winter-kill is simple and economical. Winter-kill requires no application of herbicide, mowing, or use of specialized machinery, such as crimping rollers (Ogutu, 2000) or undercutters (Creamer et al., 1995), and is compatible with organic production systems. The main disadvantage of winter-kill is the potentially high loss of residue biomass due to decomposition over the winter (Stivers-Young, 1998). In the event of a mild winter, an alternative means of management may be needed.

Barley, white mustard, and oats have been observed to winter-kill in central Illinois (Biazzo and Masiunas, 2000; Sustainable Agriculture Network, 1998). Both barley and oats have been successfully intercropped with pea in forage mixes (Carr et al., 1998; Chapko et al., 1991; Hauggaard-Nielson and Jenson, 2001) while mustard has been successfully intercropped with pea in Canada (Waterer et al., 1994).

No-till planting of 'Sparkle' snap pea into glyphosate-killed cover crop residue was investigated in Kentucky. Oats and barley interfered with snap pea establishment similarly to wheat (Triticum aestivum) and rye (Secale cereale) and less than dutch white clover (Trifolium repens), tall fescue (Festuca arundinacea), perennial ryegrass ( $L o^{-}$ lium perene), and creeping red fescue (Festuca rubra) (Weston, 1990). Unfortunately, those cover crops that interfered least with pea establishment also suppressed weed growth the least.

White mustard was identified as a good incorporated green manure preceding pea (Al-Khatib et al. 1997). In cultivated and untreated plots, white mustard green manure yielded higher pea populations than canola (Brassica napus), rye, and wheat green manures. Cultivated and untreated mustard plots yielded similarly to rye plots and significantly higher than wheat and canola plots. However, another study found that incorporated white mustard significantly reduced pea emergence (Muehlchen et al., 1990).
Oat and mustard residue may help to control pea root rot (Aphanomyces euteiches). Studies have shown oat to decrease disease organism density and increase pea yield in root rot infected soils (Fritz et al., 1995; Purdue University, 1999; WilliamsWoodward et al., 1997). White mustard reduced pea stand loss due to root rot (Lewis and Papavizas, 1971; Muehlchen et al., 1990; Papavizas, 1966) and reduced root rot inoculum density in soil and pea disease incidence in greenhouse experiments (Chan and Close, 1987).

Cover crop residues release allelopathic chemicals that suppress both weeds and diseases. Barley contains the allelochemicals gramine and hordenine (Liu and Lovett, 1994; Overland, 1966). Oat tissue contains the allelochemicals scopoletin (Fay and Duke, 1977; Martin and Rademacher, 1960) and L-tryptophan, along with coumaric, ferulic, $p$-hydroxybenzoic, syringic, and vanillic acids (Guenzi and McCalla, 1966; Kato-Noguchi et al., 1994). Mustard contains glucosinolates that decay into allelopathic isothiocyanates, nitriles, and thiocyanates (Al-Khatib et al., 1997; Boydston and Hang, 1995; Vaughn and Boydston, 1997). Even pea produces the allelochemical $\beta$-(3-isoxazolinon-5-on-2-yl)-alanine (Akemo et al., 2000).

Many questions remain regarding pea planted into winter-killed cover crops. Cover crop residue may be lost during an Illinois winter, with its limited snowfall. Surface residues of winter-killed barley, white mustard, and oat could interact differently with weeds and peas compared with unweathered herbicide-killed cover crop residues and incorporated green manures. The objectives of this study were to test cover crops for their ability to produce residue in the fall, retain that residue through spring, and suppress weeds without impacting pea yields.

\section{Materials and methods}

Field STudy. The experiments were conducted in central Illinois at the Cruise Tract Irrigated Vegetable Research Farm in Champaign County (Champaign) and in far-southern Illinois at Dixon Springs Agricultural Research Center in Pope County (Dixon Springs). The soil types were Flanagan silt-loam (fine montimorrillontic, mesic, Aquic Arguidoll) at Champaign and Grantsburg silt loam (fine-silty, mixed, mesic Typic Fragiu- dall) at Dixon Springs. The experiment was a split-plot design, the whole-plot treatment was cover crop, and the subplot treatment was weed management. There were five replications at Champaign and four replications at Dixon Springs. Each whole-plot was $3.0 \times 15.2 \mathrm{~m}(10 \times 50 \mathrm{ft})$.

'Cayuse' oats, 'UC-603' barley, and white mustard were planted at Champaign on 31 Aug. 2002 and at Dixon Springs on 30 Sept. 2002. Aseed supplier (Peaceful Valley Farm Supply, Grass Valley, Calif.) had selected the cultivars used in this experiment for high biomass production. At both locations a bare ground control treatment was included. Oats and barley were drilled at 100.9 and $134.5 \mathrm{~kg} \cdot \mathrm{ha}^{-1}$ (90 and $120 \mathrm{lb} /$ acre), respectively, in $20.3-\mathrm{cm}$ (8 inches) rows at $3.56-\mathrm{cm}$ (1.4 inch) depth. White mustard was hand broadcast at $11.2 \mathrm{~kg} \cdot \mathrm{ha}^{-1}(10$ $\mathrm{lb} / \mathrm{acre})$ and raked into the top $\mathbf{1 . 5 2}$ $\mathrm{cm}$ (0.6 inch) of soil.

Low winter temperatures killed all cover crops at Champaign. Mustard was the only cover crop to winter-kill at Dixon Springs, and all plots were sprayed with $84 \mathrm{l} \mathrm{g} \cdot \mathrm{ha}^{-1}(0.75 \mathrm{lb} /$ acre $)$ glyphosate the day of pea planting. On 24 Mar. 2003 at Champaign and 27 Mar. 2003 snap pea cultivar Mega (Territorial Seed Co., Cottage Grove, Ore.) was planted, without tillage, into the winter-killed cover crop residue at $112.1 \mathrm{~kg} \cdot \mathrm{ha}^{-1}(100 \mathrm{lb} / \mathrm{acre})$ of seed in rows spaced $38.1 \mathrm{~cm}$ (15 inches) apart at a depth of $5.1 \mathrm{~cm}$ (2 inches). At Champaign, four $15.2-\mathrm{m}$ rows of peas per whole-plot were seeded. At Dixon Springs, only three 7.3-m (24 $\mathrm{ft}$ ) rows of peas were planted.

Following the planting of snap pea, the plots were split into weedy control, hand-cultivated, and herbicide subplots. Each subplot was 4.9 $\mathrm{m}(\mathrm{l} 6 \mathrm{ft})$ long at Champaign and 2.4 $\mathrm{m}(8 \mathrm{ft})$ long at Dixon Springs. In the herbicide subplot, imazethapyr at 70.1 $\mathrm{g} \cdot \mathrm{ha}^{-1}(\mathrm{l} \mathrm{oz} / \mathrm{acre})$ was applied the day of planting peas at Dixon Springs and 1 $\mathrm{d}$ after planting at Champaign. On 14 May 2003, at Champaign, bentazon at $280 \mathrm{~g} \cdot \mathrm{ha}^{-1}(0.25 \mathrm{lb} /$ acre $)$ was applied to control broadleaf weeds less then 5.1 $\mathrm{cm}$ tall in the herbicide subplots.

The hand-cultivated subplots were hoed weekly with a colinear-type hoe from the appearance of weeds until the week before the first harvest $(23$ Apr. to 28 May), at Champaign. At Dixon Springs, the cultivated subplots 
were hoed once on 19 May. The fewer hoeings at Dixon Springs were due to slower weed emergence and less available labor. The single hoeing at Dixon Spring did not affect the yield because the weeds did not emerge until early May, a month after pea planting, and the hoeing eliminated weeds from interfering with pea harvest.

Percent ground coverage of cover crop was measured using a beaded string transect with 10 randomly located beads on a 2.4-m string (Morrison et al., 1995). In each plot, two randomly located transects were measured and combined. Measurements were made at Champaign on 3, 11 , and 24 Oct.; 8 and 19 Nov.; 13 and 20 Dec.; 7 Feb.; 5 and 25 Mar.; 17 and 24 Apr.; 1, 7, 15,22 , and 28 May; and 18 June (33, $41,54,69,80,104,111,160,186$, 206, 229, 236, 243, 249, 257, 264, 270 , and $29 \mathrm{ld}$ after planting the cover crops) and at Dixon Springs on 8 and 23 Nov.; 16 Dec.; 2 Feb.; 27 Mar.; and 19 and 29 May $(39,54,77,125$, 178,231 , and $241 \mathrm{~d}$ after planting cover crops).

Weeds in a randomly located 0.25 $\mathrm{m}^{2}\left(2.691 \mathrm{ft}^{2}\right)$ quadrat were identified and counted by dominant species. At the same time, weed and cover crop residues were sampled 2 Dec. 2002 and 2 Feb. 2003 at Champaign and Dixon Springs, respectively (following cecession of cover crop growth), 21 and 27 Mar. (preceding the planting of snap peas), and 2 June and 29 May (at first pea harvest). Cover crop and weed residues were dried for $48 \mathrm{~h}$ at $93^{\circ} \mathrm{C}\left(199.4^{\circ} \mathrm{F}\right)$ in a drying oven and dry mass determined.

Pea plant populations were counted in $1.5 \mathrm{~m}(5 \mathrm{ft})$ of the two inner rows on 22 May at Champaign and entire subplot on 29 May at Dixon Springs. Snap pea pods were harvested weekly by weighing mature pods in the same areas. Harvesting occured on 3, 10, 16 , and 23 June ( 71 to $91 \mathrm{~d}$ after pea planting) at Champaign and 26 May plus 6 and 13 June ( 63 to $78 \mathrm{~d}$ after pea planting) at Dixon Springs.

Data were analyzed using SAS (SAS Institute, 2000). Analysis of variance (ANOVA) was conducted using the mixed procedure. When necessary, data were transformed so that the residuals were normal by the Shapiro-Wilks test $(P \geq 0.005$, fail to reject $\mathrm{H}_{\mathrm{o}}=$ residuals are normal) in the UNIVARIATE procedure (Littell et al., 2002). Means were separated by Fisher's protected least significant difference (LSD) test at the comparisonwise $\alpha=0.05$ using the standard error from SAS and an appropriate tabular $t$-value.

Greenhouse study. Three experiments were conducted to evaluate the effect of residue from three species of cover crops and a bare soil control upon the germination and growth of snap pea 'Mega', common lambsquarters, and shepherd's-purse. Shepherd's-purse was included to represent a common winter annual weed that would be present with winterkilled cover crops.

Each of the three test species were in separate experiments, independently randomized and physically separate, although they were conducted simultaneously. The experiments used a 1:1 mixture of Drummer silty-clay-loam to coarse sand. After seeding, cover crop residue from the field experiment was applied to the soil surface at a rate corresponding to a dry weight of 4000 $\mathrm{kg} \cdot \mathrm{ha}^{-1}$ (3569 lb/acre). Twelve-hour day and night set temperatures were 25 and $22^{\circ} \mathrm{C}\left(77.0\right.$ and $\left.71.6^{\circ} \mathrm{F}\right)$, respectfully. The soil was kept moist with 1 to $2 \mathrm{~cm}(0.39$ to 0.79 inch) of daily watering. No fertilization occurred.

Six snap pea seeds were planted $1.5 \mathrm{~cm}(0.59$ inch $)$ deep into 18 -cell flats filled with $300 \mathrm{~cm}^{3}\left(18.3 \mathrm{inch}^{3}\right)$ soil mix. Germinated pea seedlings were counted three weeks after planting and again when the experiment was terminated. At termination, shoots were oven dried at $93^{\circ} \mathrm{C}$ for $48 \mathrm{~h}$ and dry weight was determined.

Each cell of a 32-cell flat was filled with $180 \mathrm{~cm}^{3}$ (11.0 inch ${ }^{3}$ ) soil mix and $\sim 50$ seeds of common lambsquarters and shepherd's-purse were placed on the soil. Fifty seeds were approximated by $21.6 \mathrm{mg}(0.00076 \mathrm{oz})$ common lambsquarters seeds and by $5.0 \mathrm{mg}$ $(0.00018 \mathrm{oz})$ shepherd's-purse seeds. These weights were the average of seven lots of 50 randomly selected seeds. Weed seedlings were counted 3 weeks after planting and again when the experiment was terminated. Fresh weight of the weed seedlings was determined. Because the shoots were small, dry weight was not measured.

Each experiment was repeated three times. Within each repeat there were five blocked replications. Repeats were conducted under natural daylight from 13 Dec. 2002 to 21 Jan. 2003
(40 d); 8 Jan. to 12 Feb. ( 35 d), and 18 Feb. to 20 Mar. (30 d).

Data were analyzed using SAS. Analysis of variance was conducted using the mixed procedure. When necessary, data was transformed so that the residuals were normal by the Shapiro-Wilks test $(P \geq 0.005$, fail to reject $\mathrm{H}_{\mathrm{o}}=$ residuals are normal) in the UNIVARIATE procedure (Littell, 2002). When the effect of cover crop species was significant, means were separated by Fishers protected LSD.

\section{Results and discussion}

Field EXPERIMENT. The cover crop species affected surface coverage of the residues at Champaign, except for on the last sampling date $(291 \mathrm{~d}$ after planting cover crops) (Fig. 1). On the last sampling date, the cover crop residues had decayed so surface coverage from each species was similar. There was more surface coverage for barley residues than for oat residue from the first measurement until the planting of pea (33 to $206 \mathrm{~d}$ after planting cover crops). During the fall growing season, there was no difference in ground cover between monocots (barley and oats) and mustard. Following the first hard frost at $94 \mathrm{~d}$ after planting, mustard died and its leaves started to decay. This caused monocots to have higher ground cover than mustard for the remainder of the experiment.

Cover crop residue biomass was effected by species and sampling date (Table 1). When cover crop growth ceased at the first hard freeze ( 3 Dec.), oat and barley residues had similar biomass. Mustard produced more biomass [5780 kg.ha ${ }^{-1}(5157 \mathrm{lb} /$ acre $\left.)\right]$, than barley $\left[4200 \mathrm{~kg} \cdot \mathrm{ha}^{-1}(3747 \mathrm{lb} /\right.$ acre $\left.)\right]$, and oat $\left[3660 \mathrm{~kg} \cdot \mathrm{ha}^{-1}(3265 \mathrm{lb} / \mathrm{acre})\right]$. However, the lower biomass production by monocots compared with mustard was not reflected in significantly lower ground cover. By spring pea planting on 21 Mar., barley had greater biomass [4750 kg.ha ${ }^{-1}(4238$ $\mathrm{lb} /$ acre $)]$ than oats $\left[3450 \mathrm{~kg} \cdot \mathrm{ha}^{-1}\right.$ (3078 lb/acre)], while mustard [2200 $\left.\mathrm{kg} \cdot \mathrm{ha}^{-1}(1963 \mathrm{lb} / \mathrm{acre})\right]$ had the least biomass. The two monocots had higher biomass due to the mustard's leaves decaying quicker than the monocots' leaves. These results agree with research in New York, where mustard lost a greater percentage of its biomass than oats (Stivers-Young, 1998). However, Stivers-Young (1998) found similar oat and mustard weight in the spring 


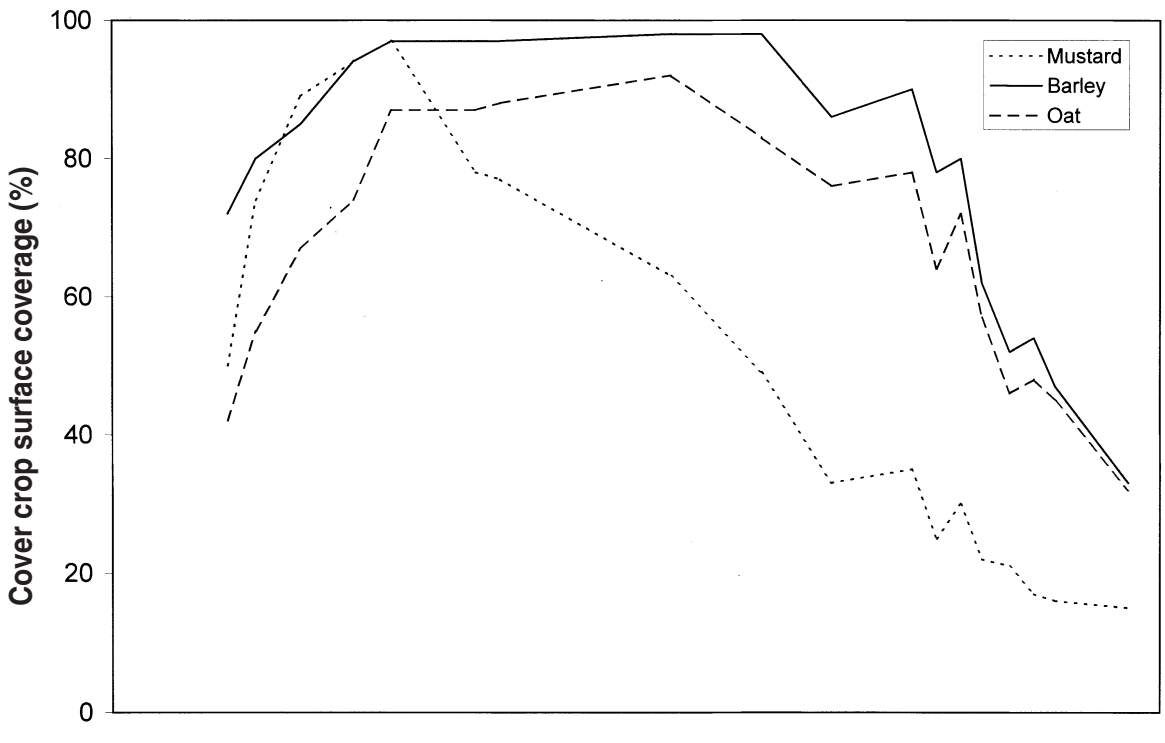

Time after planting (d)

Fig. 1. The percent ground coverage by residue of mustard, barley, and oats at the Cruise Tract Irrigated Vegetable Research Farm in Champaign County, Ill.

because of higher mustard residue production in the fall.

Residue biomass of the cover crop species did not differ on 7 June, because residues had largely decayed. The mustard had less residue decay than the monocot species between pea planting and harvest because its residue at planting consisted mostly of woody stem tissue. Stivers-Young (1996) observed quick decay of mustard leaves, while stem tissue was more resistant.

There was a significant species $\times$ date interaction on surface coverage $(P$ $=0.0010)$ at Dixon Springs. At 125 and $178 \mathrm{~d}$ after planting cover crops (late winter and at pea planting), the effect of species was significant with the monocots having higher ground cover than mustard (data not shown).

Table 1. The effect of cover crop species on dry weight of residue at different times after planting at Champaign, Ill.

\begin{tabular}{|c|c|c|c|}
\hline \multirow{2}{*}{$\begin{array}{l}\text { Cover } \\
\text { crop }\end{array}$} & \multicolumn{3}{|c|}{ Dry wt of cover crops } \\
\hline & 3 Dec. $^{z}$ & 22 Mar. & 7 June \\
\hline & \multicolumn{3}{|c|}{-..-.- kg.ha-ly } \\
\hline & $5780 \mathrm{a}^{\mathrm{x}}$ & $2200 \mathrm{c}$ & 1000 \\
\hline & 4200 & & 1200 \\
\hline Oat & $3660 \mathrm{~b}$ & $3450 \mathrm{~b}$ & 1700 \\
\hline
\end{tabular}

${ }^{2}$ The sampling dates were: 3 Dec., after a killing frost; 22 Mar., before pea planting; and 3 June, at the first pea harvest.

y $1 \mathrm{~kg} \cdot \mathrm{ha}^{-1}=0.89 \mathrm{lb} /$ acre.

${ }^{x}$ Means within column followed by the same letter are not significantly different according to Fishers protected least significant difference test at $P \leq 0.05$.
Barley and oats residues had similar residue biomass, while producing more biomass than mustard. Mustard performed poorly in the cool, moist, late fall weather at Dixon Springs.

The predominant weed species in the fall at Champaign was the summer annual, common lambsquarters, which did not succeed in setting seed and was killed by the first hard freeze. Therefore, weed populations in the spring were not a direct continuation of weed populations in the fall. On 2 Dec., the bare ground control treatment had more weed biomass than the cover crop treatments, which were not significantly different (Table 2). At pea harvest, on 2 June, there was a significant cover crop species by weed management treatment interaction ( $P$ $<0.0001)$. Within the weedy treat- ment, mustard and the bare ground control treatments had less weed biomass than oat and barley (Table 2 ). In the herbicide treatment, the bare ground control treatment had less weed biomass than in the cover crop treatments. The cultivated treatment was maintained almost weed-free, so there were no differences among the cover crops.

The cover crop species $\times$ weed management interaction did not affect total number of weeds at the beginning of pea harvest (Table 3). The cover crop main effect also was nonsignificant, and weed counts were similar across all cover crop treatments. Few weeds overwintered, and the count of winter annual, biennial, and perennial weeds that potentially overwintered was not different between the cover crop treatments (Table 3). The greatest differences in weed density were due to the supplemental weed control treatments. The weedy treatment generally had higher weed density than the herbicide treatment, which had equal or higher weed density than the cultivated treatment.

The year before this experiment at Dixon Springs, the field was fallow with only periodic mowing for weed management. The predominant weed species were grasses such as annual bluegrass ( Poa annua), barnyardgrass (Echinochloa crusgalli), goosegrass (Eleusine indica), and tall fescue. Many weeds, such as tall fescue, horsenettle (Solanum carolinense), common milkweed (Asclepias syriaca), virgina pepperweed (Lepidum virginicum), field bindweed (Convolvulusarvensis), black medic (Medicago lupulina), and wild garlic (Allium vineale) overwintered. Many established perennial weeds were not killed by preplant tillage. On 2 Feb.

Table 2. The effect of cover crop and management treatment on above ground weed dry biomass in Champaign, Ill., after a killing frost, on 2 Dec. 2002 and a day before the beginning of pea harvest. No living weeds were present on 21 Mar. 2003 at pea planting.

\begin{tabular}{|c|c|c|c|c|}
\hline \multirow{2}{*}{$\begin{array}{l}\text { Cover } \\
\text { crop }\end{array}$} & \multirow{2}{*}{$\begin{array}{c}\text { Weed } \\
\text { biomass } \\
\text { on } 2 \text { Dec. }\end{array}$} & \multicolumn{3}{|c|}{$\begin{array}{c}\text { Weed dry wt on } 2 \text { June } \\
\text { Weed management treatment }\end{array}$} \\
\hline & & Cultivation & Herbicide & Non-weeded \\
\hline Control & $1720 \mathrm{a}^{\mathrm{y}}$ & 5.6 & $336 \mathrm{a}$ & $1120 \mathrm{~b}$ \\
\hline Mustard & $120 \mathrm{~b}$ & 8.8 & $12.0 \mathrm{~b}$ & $1070 \mathrm{~b}$ \\
\hline Barley & $96 \mathrm{~b}$ & 11.0 & $11.0 \mathrm{~b}$ & $2330 \mathrm{a}$ \\
\hline Oat & $420 \mathrm{~b}$ & 16.0 & $28.0 \mathrm{~b}$ & $2600 \mathrm{a}$ \\
\hline
\end{tabular}

${ }^{2} \mathrm{l} \mathrm{kg} \cdot \mathrm{ha}^{-1}=0.89 \mathrm{lb} /$ acre

${ }^{y}$ Means within column followed by the same letter are not significantly different according to Fishers

protected least significant difference test at $P \leq 0.05$. 
Table 3. The effect of cover crop species and weed management treatment on the number of weeds a day before the beginning of pea harvest in Champaign, Ill.

\begin{tabular}{|c|c|c|c|c|c|c|c|c|}
\hline $\begin{array}{l}\text { Cover } \\
\text { crop }\end{array}$ & $\begin{array}{c}\text { Weed } \\
\text { management }^{\mathrm{z}}\end{array}$ & CHEAL $^{y}$ & ABUTH & Pigweed & $\begin{array}{c}\text { Total } \\
\text { broadleaf } \\
\text { weeds }\end{array}$ & Grass & $\begin{array}{l}\text { Winter annual } \\
\text { and perennial } \\
\text { weeds }^{x}\end{array}$ & $\begin{array}{c}\text { Total } \\
\text { weeds }\end{array}$ \\
\hline & & & & & $-\mathrm{No} . / \mathrm{m}^{2 \mathrm{w}}$ & & & - \\
\hline & Herb & 0.0 & 0.0 & 0.0 & 6.4 & 0.0 & 1.6 & 8.0 \\
\hline & Weedy & 19.2 & 8.8 & 33.6 & 99.2 & 0.0 & 4.0 & 103.2 \\
\hline & Weedy & 131 & 1.6 & 14.4 & 154 & 0.0 & 0.8 & 154.8 \\
\hline \multirow[t]{3}{*}{ Barley } & Cult & 17.6 & 1.6 & 2.4 & 31.2 & 0.0 & 2.4 & 33.6 \\
\hline & Herb & 8.0 & 0.0 & 0.0 & 8.0 & 0.8 & 0.0 & 8.8 \\
\hline & Weedy & 280 & 0.0 & 0.0 & 295 & 0.0 & 4.0 & 299 \\
\hline \multirow[t]{2}{*}{ Oat } & Cult & 14.4 & 0.0 & 7.2 & 34.4 & 0.0 & 7.2 & 41.6 \\
\hline & Herb & 64.0 & 0.0 & 1.6 & 67.2 & 0.0 & 0.8 & 68.0 \\
\hline
\end{tabular}

${ }^{2}$ The weed management treatments were: Cult = cultivated and hand-hoed; Herb = imazethapyr applied $1 \mathrm{~d}$ after pea planting and bentazon was applied on 14 May; Weedy $=$ the treatment were not weeded.

yThe weeds present were: CHEAL $=$ common lambsquarters $($ Chenopodium album $) ; \mathrm{ABUTH}=\operatorname{velvetleaf}($ Abutilon theophrasti); pigweed $=$ smooth pigweed $($ Amaranthus hybridus), powell amaranth (Amaranthus powellii), and redroot pigweed (Amaranthus retroflexus). In addition to these weeds, total broadleaf weeds also include: horseweed (Conyza canadensis); jimsonweed (Datura stramonium); pennsylvania smartweed (Polygonum pennsylvanicum); common purslane (Portulaca oleracea), common chickweed (Stellaria media), eastern black nightshade (Solanum ptycanthum), dandelion (Taraxacum officinale), and field pennycress (Thlaspi arvense).

${ }^{x}$ Winter annual and perennial weeds include common chickweed, dandelion, field pennycress, and horseweed.

w $1.0 \mathrm{~m}^{2}=10.76 \mathrm{ft}^{2}$.

and 27 Mar., the bare ground treatment had greater weed biomass than the mean weed biomass for the cover crop treatments (data not shown). There were no differences in weed biomass among the cover crop treatments.

Total pod weight was not affected by the cover crop species $x$ weed management interaction $(P=0.1539)$ at Champaign, but the species $(P=$ $0.0002)$ and weed management $(P<$ $0.0001)$ main effects were significant. Total weight of pea pods was greatest in the mustard $\left[10,100 \mathrm{~kg} \cdot \mathrm{ha}^{-1}(901 \mathrm{llb} /\right.$ acre)], followed by the control [ 5780 $\mathrm{kg} \cdot \mathrm{ha}^{-1}(5157 \mathrm{lb} /$ acre $\left.)\right]$, then the oat $\left[7370 \mathrm{~kg} \cdot \mathrm{ha}^{-1}(6575 \mathrm{lb} / \mathrm{acre})\right]$ and barley $\left[6250 \mathrm{~kg} \cdot \mathrm{ha}^{-1}(5576 \mathrm{lb} /\right.$ acre $\left.)\right]$ treatments (Fig. 2). When the subplot treatments were compared, total pea pod weight in the cultivated treatment [9770 kg.ha ${ }^{-1}$ (8717 lb/acre)] was the greatest, followed total weight in the herbicide treatment $\left[8150 \mathrm{~kg} \cdot \mathrm{ha}^{-1}\right.$ $(727 \mathrm{lb} / \mathrm{acre})]$, and total weight in the weedy treatment was the least [5200 $\mathrm{kg} \cdot \mathrm{ha}^{-1}$ (4639 lb/acre)].

When weeds were mechanically controlled in the cultivated system, the pea pod weight was not affected by cover crop treatment. Therefore, the physical presence of cover crop residue did not negatively impact snap pea yields. Although we used handhoeing for mechanical weed control, cultivators have been developed for high residue systems which maintain

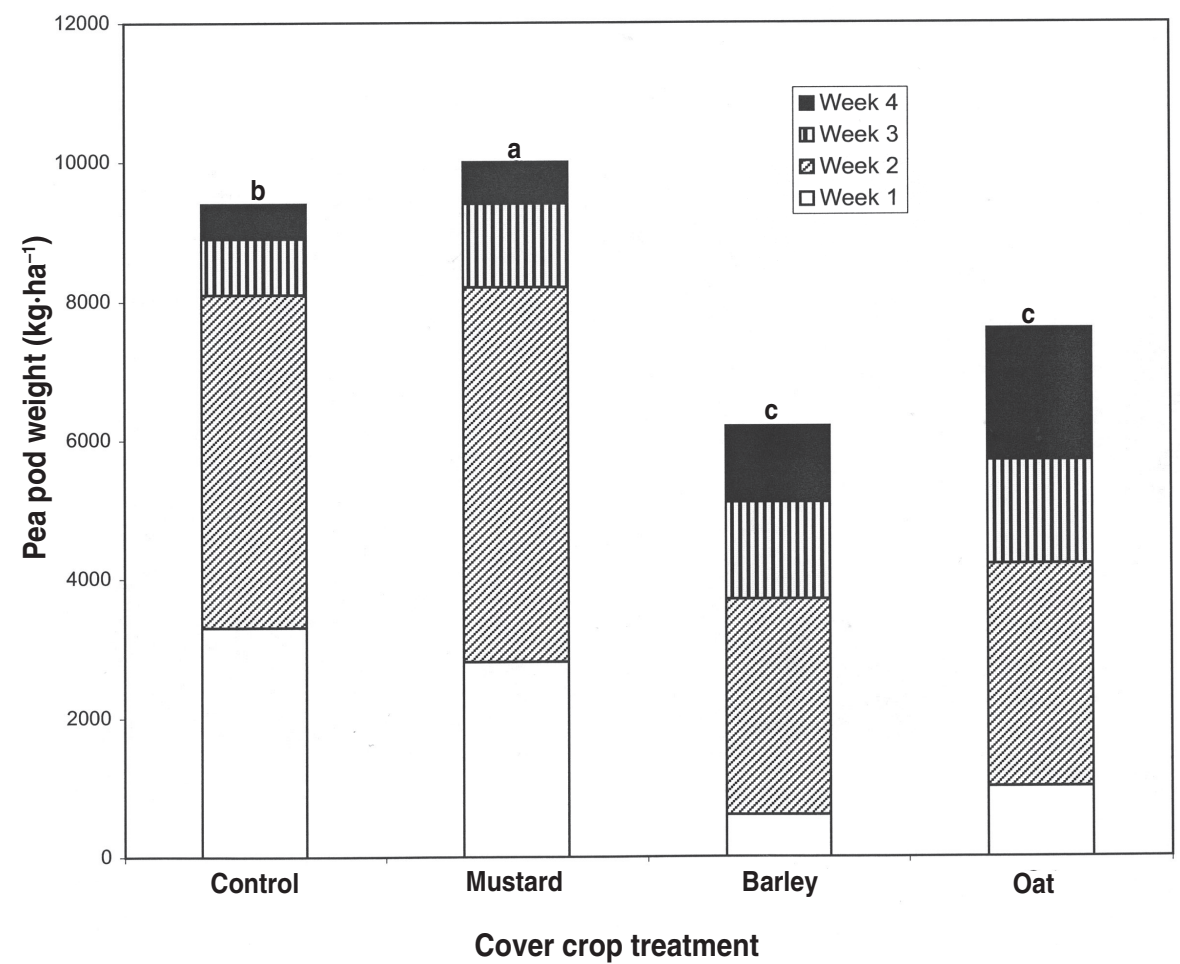

Fig. 2. The effect of cover crop treatment on snap pea pod fresh weight at the Cruise Tract Irrigated Vegetable Research Farm in Champaign County, Ill. Individual harvests are stacked to produce total yield. Total yield means with the same letter are not significantly different according to Fishers protected least significant difference test at $P \leq 0.05\left(1 \mathrm{~kg} \cdot \mathrm{ha}^{-1}=0.89 \mathrm{lb} /\right.$ acre $)$. 
surface cover and could be used by larger-acreage vegetable growers. Previous research with mustard and oat cover crops found either small negative impacts on pea growth (Muehlchen et al., 1990) or no impacts on pea growth (Al-Khatib et al., 1997). In the weedy system, pea yields were higher in the mustard and control than in the oat and barley treatments. The low pea yield in the latter two cover crop treatments was probably due to increased weed pressure. In the herbicide system, pea yields were better in the mustard than barley or oats treatments. Mustard was the only cover crop species to have the highest yields among all weed control treatments.

Greenhouse STUdy. Cover crop species did not affect pea emergence or dry weight. The presence of cover crop residue negatively affected the emergence of common lambsquarters and shepherd's-purse, reducing emergence by over $50 \%$ as compared with the control (Table 4). The presence or absence of cover crop residues did not impact snap pea growth or yield. Previous studies also found reduced pea emergence in white mustard residue (Muehlchen et al., 1990) and reduced snap pea establishment in barley and oat residue (Weston, 1990). However, another study found oat and mustard did not negatively affect pea (Al-Khatib et al., 1997).

The response of weeds to cover crop residue was different in the field and greenhouse studies. In the greenhouse study, cover crop residue at 4000 $\mathrm{kg} \cdot \mathrm{ha}^{-1}$ reduced shepherd's-purse and common lambsquarters emergence and fresh weight. However, in the field study similar spring cover crop biomass and surface cover did not translate into lower lambsquarters counts, surface cover, or biomass. Large amounts of oat and barley residues resulted in large stands of common lambsquarters that negatively impacted snap pea yield. This may have been caused by high soil moisture under the oat and barley residues (data not shown). A drier soil surface in the mustard and control treatments may have resulted in less common lambsquarters germination during the early season. Teasdale et al. (1991) reported a similar response by common lambsquarters to moisture under cover crops. Soil moisture was a controlled factor in the greenhouse, which may be why this effect was not observed. In the greenhouse, reduced

Table 4. The effect of cover crop on the emergence of common lambsquarters, shepherd's-purse, and snap pea in a greenhouse study.

\begin{tabular}{lccc}
\hline $\begin{array}{l}\text { Cover } \\
\text { crop }\end{array}$ & $\begin{array}{c}\text { Common } \\
\text { lambsquarters }\end{array}$ & Shepherds-purse & $\begin{array}{c}\text { Snap } \\
\text { pea }\end{array}$ \\
\hline Control & $-37 \mathrm{a}^{\mathrm{z}}$ & $23 \mathrm{a}$ & 64 \\
Mustard & $19 \mathrm{~b}$ & $10 \mathrm{~b}$ & 52 \\
Barley & $17 \mathrm{~b}$ & $7 \mathrm{~b}$ & 58 \\
Oat & $21 \mathrm{~b}$ & $12 \mathrm{~b}$ & 53 \\
\hline
\end{tabular}

${ }^{2}$ Means within column followed by the same letter are not significantly different according to Fishers protected least significant difference test at $P \leq 0.05$. There were no differences in snap pea emergence.

common lambsquarters germination under residue was probably due to reduced light levels with the residues (Teasdale, 1993). Previous work with winter-killed oat and mustard residues at similar weights found both to significantly reduce weed growth in the field, perhaps due to a different weed spectrum at the study site (StiversYoung, 1998).

Only a minor increase in pod yield and no measurable weed control are obtained by the planting of white mustard preceding spring snap pea with no supplemental weed control. With supplemental weed control, no weed control or yield advantage is obtained by the planting of winterkilled cover crops preceding spring snap peas. Since supplemental weed control is usually provided and since seeding of a cover crop is an additional production expense, to plant a cover crop for weed control would not be economically advantageous. However, if a fall cover crop is desired for erosion control, as a nutrient trap crop, or to meet regulatory requirements, white mustard, which had similar yields to the control, is most suitable for preceding snap pea in central midwestern United States.

\section{Literature cited}

Akemo, M.C., E.E. Regnier, and M.A. Bennett. 2000. Weed suppression in spring-sown rye Secale cereale)-pea (Pisum sativum) cover crop mixes. Weed Technol. 14:545-549.

Al-Khatib, K., C. Libby, and R. Boydston. 1997. Weed suppression with Brassica green manure crops in green pea. Weed Sci. 45:439-445.

Biazzo, J. and J.B. Masiunas. 2000. The use of living mulches for weed management in hot pepper and okra. J. Sustainable Agr. 16:59-79.
Boydston, R.A. and A. Hang. 1995. Rapeseed (Brassica napus) green manure crop suppresses weeds in potato (Solanum tuberosum). Weed Technol. 9:669-675.

Carr, P.M., G.B. Martin, J.S. Caton, and W.W. Poland. 1998. Forage and nitrogen yield of barley-pea and oat-pea intercrops. Agron. J. 90:79-84.

Chan, M.K.Y. and R.C. Close. 1987. Aphanomyces root rot of peas. 3. Control by use of cruciferous amendments. N.Z. J. Agr. Res. 30:225-233.

Chapko, L.B., M.A. Brinkman, and K.A. Albrecht. 1991. Oat, oat-pea, barley, and barley-pea for forage yield, forage quality, and alfalfa establishment. J. Prod. Agr. 4:486-491.

Creamer, N.G., B. Plassman, M.A. Bennett, R.K. Wood, B.R. Stinner, and J. Cardina. 1995. A method for mechanically killing cover crops to optimize weed suppression. Amer. J. Alternative Agr. 10:157-162.

Fay, P.K. and W.B. Duke. 1977. An assessment of allelopathic potential in Avena germplasm. Weed Sci. 25:224-228.

Fritz, V.A., R.R. Allmaras, F.L. Pfleger, and D.W. Davis. 1995. Oat residue and soil compaction influences on common root$\operatorname{rot}$ (Aphanomyceseuteiches) of peas in a finetextured soil. Plant Soil 171:235-244.

Guenzi, W.D. and T.M. McCalla. 1966. Phenolic acids in oat, wheat, sorghum, and corn residues and their phytotoxicity. Agron. J. 58:303-304.

Hauggaard-Nielsen, H. and E.S. Jensen. 2001 . Evaluating pea and barley cultivars for complementarity in intercropping at different levels of soil $\mathrm{N}$ availability. Field Crop Res. 72:185-196.

Hoyt, G.D., D.W. Monks, and T.J. Monaco. 1994. Conservation tillage for vegetable production. HortTechnology 4:129-135.

Kato-Nogchi, H., S. Kosemura, S. Yamamura, J. Mitzutani, and K. Hasegawa. 1994. Allelopathy of oats. I. Assessment of 
allelopathic potential of extract of oat shoots and identification of an allelochemical. J. Chem. Ecol. 20:309-314.

Lewis, J.A. and G.C. Papavizas. 1971. Effect of sulfur-containing volatile compounds and vapors from cabbage decomposition on Aphanomyces euteiches. Phytopathology 61:208-214.

Littell, R.C., W.W. Stroup, and R.J. Freund. 2002. SAS for linear models. 4th ed. SAS Inst., Cary, N.C.

Liu, D.L. and J.V. Lovett. 1994. Biologically active secondary metabolites of barley. II. Phytotoxicity of barley allelochemicals. J. Chem. Ecol. 19:2231-2244.

Martin, P. and B. Rademacher. 1960. Studies on the mutual influences of weeds and crops. Br. Ecol. Soc. Symp. 1:143-152.

Morrison, J.E., Jr., J. Lemunyon, and H.C. Bugusch Jr. 1995. Sources of variation of nine devices when measuring percent residue ground cover. Trans. Amer. Soc. Agr. Eng. 38:521-529.

Muehlchen, A.M., R.E. Rand, and J.L. Parke. 1990. Evaluation of crucifer green manures for controlling Aphanomyces root rot of peas. Plant Dis. 75:651-654.

Ogutu, M.O. 2000. Developing methods of strip cropping cucumbers with rye/ vetch. PhD Diss., Virginia Polytechnic Inst. and State Univ., Blacksburg.

Overland, L. 1966. The role of allelopathic substances in the "smother crop" barley. Amer. J. Bot. 53:423-432.

Papavizas, G.C. 1966. Suppression of Aphanomyces root rot of pea by cruciferous soil amendments. Phytopathology 56:1071-1075

Purdue University. 1999. Midwest vegetable production guide for commercial growers, p. 71. Purdue Univ. Coop. Ext., West Lafayette, Ind.
Sustainable Agriculture Network. 1998. Managing cover crops profitably. 2nd ed. Sustainable Agr. Network Natl. Agr. Library, Beltsville, Md.

Stivers-Young, L. 1998. Growth, nitrogen accumulation, and weed suppression by fall cover crops following early harvest of vegetables. HortScience 33:60-63.

Teasdale, J.R. 1993. Interaction of light, soil moisture, and temperature with weed suppression by hairy vetch residue. Weed Sci. 41:46-51.

Teasdale, J.R. 1996. Contributions of cover crops to weed management in sustainable agriculture systems. J. Prod. Agr. 9:475-479.

Teasdale, J.R., C.E. Beste, and W.E. Potts. 1991. Response of weeds to tillage and cover crop residue. Weed Sci. 39:195-199.

Vaughn, S.F. and R.A. Boydston. 1997. Volatile allelochemicals released by crucifer green manures. J. Chem. Ecol. 23:2107-2116.

Waterer, J.G., J.K. Vessey, E.H. Stobbe, and R.J. Soper. 1994. Yield and symbiotic nitrogen-fixation in a pea-mustard intercrop as influenced by $\mathrm{N}$ fertilizer addition. Soil Bio. Biochem. 26:447-453.

Weston, L.A. 1990. Cover crop and herbicide influence on row crop seedling establishment in no-till culture. Weed Sci. 38:166-171.

WilliamsWoodward, J.L., F.L. Pfleger, V.A. Fritz, and R.R. Allmaras. 1997. Green manures of oat, rape, and sweet corn for reducing common root rot in pea (Pisum sativum) caused by Aphanomyces eueiches. Plant Soil 188:43-48. 